\title{
ACCUMULATION OF HEAVY METALS IN DIFFERENT BODY TISSUES OF GIBEL CARP CARASSIUS GIBELIO SEPARATELY EXPOSED TO A MODEL MIXTURE (Cu, Zn, Ni, Cr, Pb, Cd) AND NICKEL
}

\author{
Gintaras SVECEVIČIUS ${ }^{\mathrm{a}}$, Raimondas Leopoldas IDZELIS ${ }^{\mathrm{b}}$, Eglè MOCKUTE் \\ ${ }^{a}$ Nature Research Centre, Akademijos g. 2, 08412 Vilnius, Lithuania \\ ${ }^{b}$ Vilnius Gediminas Technical University, Sauletekio al. 11, 10223 Vilnius, Lithuania
}

Submitted 26 Jul. 2013; accepted 19 May 2014

\begin{abstract}
Heavy metals (HMs) are common persistent pollutants of aquatic ecosystems, which have a property to migrate and accumulate in water organisms. Little information has been compiled on HM accumulation and the interactions between them in fish exposed to their mixtures at environmentally-relevant concentrations. The aim of the present study was to determine accumulation patterns of $\mathrm{Cu}, \mathrm{Zn}, \mathrm{Ni}, \mathrm{Cr}, \mathrm{Pb}$ and $\mathrm{Cd}$ in the muscle, gills and liver of Gibel carp after 14-day exposure to HM model mixture (HMMM) and to Ni separately, at concentrations corresponding to Lithuanian inland water standards (Cu-0.01; Zn-0.1; Ni-0.01; Cr-0.01; Pb-0.005; Cd-0.005 mg/l, respectively). Laboratory tests were conducted on adult Gibel carp under semi-static conditions. The amounts of HMs in the water and body tissues were determined using atomic absorption spectrophotometry (AAS). Heavy metal accumulation order in body tissues of Gibel carp was as follows: muscle > gills $>$ liver. The highest amounts found were of $\mathrm{Zn}$ $(15.2 \mathrm{mg} \mathrm{kg})$, while the lowest of $\mathrm{Cd}(0.012 \mathrm{mg} / \mathrm{kg})$. In the muscle and gills, HMs were accumulated in the following order: $\mathrm{Zn}>\mathrm{Cu}>\mathrm{Ni}>\mathrm{Cr}>\mathrm{Pb}>\mathrm{Cd}$, while in the liver: $\mathrm{Zn}>\mathrm{Cu}>\mathrm{Pb}>\mathrm{Ni}>\mathrm{Cr}>\mathrm{Cd}$. Meanwhile, the Ni concentration in HMMM-exposed fish liver and gills were significantly higher than in Ni-exposed fish. Data obtained showed that HM accumulation in Gibel carp body tissues was metal and tissue specific, i.e. different tissues showed a different capacity for accumulating HMs. Metals in mixture promoted Ni accumulation in test fish gills and liver under different experimental conditions due to the synergistic effects among them. Although the HM content in Gibel carp different body tissues increased in all cases (average of 49 to 224\%) they did not exceed Maximum-Permissible-Amounts (MPA) indicated in the Lithuanian Hygiene Standard.
\end{abstract}

Keywords: water pollution, fish, Gibel carp, heavy metals, accumulation, Bioconcentration factor (BCF), MaximumPermissible-Concentration (MPC), Maximum-Permissible-Amounts (MPA).

\section{Introduction}

Heavy metals (HMs) are a serious threat to the aquatic environment because of their toxicity, accumulation and magnification in organisms, causing severe damage to the organ-systems leading to innumerable health hazards (Roy 2010).

Copper, zinc, nickel, chromium, cadmium and lead are widely used in various anthropogenic activities. These are common persistent water pollutants, and are assigned to priority hazardous substances (Directive 2000/60/EC of the European Parliament and the Council 2000; US EPA 2009). All these metals migrate in ecosystems, accumulate in aquatic animals, presumably through binding to metallothioneins or other metal-binding proteins (Valavanidis et al. 2006).
Fish are unique among the vertebrates, a consequence of having two routes of metal acquisition, from the water and from the diet (the gill and intestinal epithelium uptake processes) (Bury et al. 2003). However, the result of the bioaccumulation process is strongly associated with the metal depuration rate and metabolic activity in different fishes.

Numerous field and laboratory studies showed that HM accumulation in fish depends on a complexity of a lot biotic and abiotic factors such as: the species, its trophic level and feeding habits, age and size, interspecific differences in sensitivity to various metals, accumulative-metabolic activity, pollutant concentration in water, sediment and food-objects, physico-chemical characteristics of the water, chemical speciation of the metal and

Corresponding author: Gintaras Svecevičius

E-mail: gintaras.svecevicius@takas.lt 
its bioavailability (Clearwater et al. 2002; Canli, Atli 2003; Green, Knutzen 2003; Papagiannis et al. 2004; Licata et al. 2005; Nemova 2005; Jezierska, Witeska 2006; Luczynska, Tonska 2006; Karthikeyan et al. 2007; Oymak et al. 2009; Polak-Juszczak 2009).

It should be noted that fish are not only an important source of animal protein in human nutrition, which quality on HM content should be continuously monitored in order to evaluate the risk to human health. Because of their property to accumulate persistent pollutants fish are an excellent bioindicators of ecotoxicological state of the aquatic environment (Chovanec et al. 2003; Nemova 2005; Has-Schön et al. 2006; Schmitt et al. 2007; Klavins et al. 2009).

Most studies of the effects of metals on fish are addressed to a particular metal. Meanwhile, in the natural environment, fish are exposed to different HM mixtures, which are usually more toxic than individual metal as their action is additive or more-than-additive (synergistic). It seems that interaction between different metals are related to their competitive uptake from the environment and to different distribution in fish tissues, which results from that certain metals affect the accumulation of other metals in fish (Jezierska, Sarnowski 2002).

Although the influence of the presence of particular metals in the medium on accumulation of others in fish has been proved experimentally (Van Hoof, Nauwelaers 1984; Ribeyre et al. 1995; Ghosh, Adhikari 2006; Ghosh et al. 2007; Palaniappan, Karthikeyan 2009) such investigations still remain rather scarce, however.

Furthermore in the accumulation tests, fish are usually exposed to relatively high non-realistic nearly lethal or even lethal HM concentrations, which are much higher than those environmentally-relevant in natural waters. The results from such studies could be hardly extrapolated to natural conditions (Van Hoof, Nauwelaers 1984; Karthikeyan et al. 2007; Palaniappan, Karthikeyan 2009).

Actually, in most natural waters, the concentrations of HMs are quite low and strictly depended on water chemistry and metal chemical speciation (the equilibrium between an ionic and metal-ligand complexation level) in the water and deposed in the bottom sediments (Van Briesen et al. 2010). Little information is compiled on accumulation in fish exposed to environmentally realistic, metal concentrations simulating those, which could occur in an ordinary environment. Therefore, the modelling of the situation which could actually take place in natural waters is required.

Recently, the implementation of the European Parliament and Council Directive 2000/60/EC establishing a Community action in the field of water policy, and taking into account the European Commission recommendation 2006/283/EC, new Lithuanian inland water standards - Maximum-Permissible-Concentrations (MPC) for representative polluting substances have been accepted. The question arises whether these limits are actually safe and can completely protect aquatic life from harmful toxic effects.

The aim of the present study was to determine experimentally the patterns of accumulation of $\mathrm{HMs}(\mathrm{Cu}, \mathrm{Zn}$, $\mathrm{Ni}, \mathrm{Cr}, \mathrm{Pb}, \mathrm{Cd}$ ) in different body tissues of Gibel carp (muscle, gills, liver), after 14-day exposure to their model mixture (HMMM) and to Ni separately at concentrations corresponding to MPC. Nickel was chosen because according to the results of monitoring studies of HM accumulation in fish and bottom sediments in Lithuania (Projekto... 2004), this metal often exceeds the levels recommended for human consumption in fish from natural water bodies. Actually, this study is a continuation of recently-started series of the works on experimental investigation of HM accumulation in freshwater fish of Lithuania (Idzelis et al. 2008, 2010).

\section{Material and methods}

The tests were conducted on Gibel carp Carassius gibelio (Bloch 1782) adults. The fish were collected in Arnionys fish hatchery ponds (Švenčionys District, Lithuania). Average total length of test fish was $104 \pm 5 \mathrm{~mm}$, and the total weight was $21 \pm 3 \mathrm{~g}$ (mean $\pm \mathrm{SEM}, n=30$, respectively). The fish were acclimated to laboratory conditions for one week prior to testing. They were kept in flow-through 1000-litre holding tanks supplied with aerated deep-well water (minimum flow rate 1 litre per 1 gram of their wet body mass per day), under natural illumination and were fed commercial fish feed (SKRETTING T-2P Supra) daily in the morning; the total amount was no less than $1 \%$ of their wet body mass per day. During the tests, the fish were fed in the same manner.

Reagent grade HM salts ("REACHIM" Company, Russia) were used as the toxicants. Stock solution was prepared by dissolving necessary amount of the salt in distilled water, the final concentration being recalculated according to the amount of HM ion.

Deep-well water was used as the dilution water. Average hardness of the water was approximately 284 (271296) $\mathrm{mg} / \mathrm{l}$ as $\mathrm{CaCO}_{3}$, alkalinity was $200(190-210) \mathrm{mg} / \mathrm{l}$ as $\mathrm{CaCO}_{3}$, $\mathrm{pH}$ ranged from 7.9 to 8.1 , temperature was maintained at 14 to $16^{\circ} \mathrm{C}$, dissolved oxygen concentration was maintained at 8 to $10 \mathrm{mg} / \mathrm{l}$, and dissolved organic carbon (DOC) was less than the detection limit $(<0.3 \mathrm{mg} / \mathrm{l})$.

The tests were conducted under semi-static conditions on three groups of 10 individuals using glass tanks of 30 -litre total volume $(20 \times 30 \times 50 \mathrm{~cm}$ in size) filled to a level of $2 / 3$ with continuously aerated dilution water. Test fish were exposed for the 14-day period to a HM model mixture (HMMM) and separately to Ni (Table 1). Test solutions and clean water were renewed every day, and test 
fish were transferred into freshly prepared solutions after they were fed.

After the testing was completed, fish (of control and metal-exposed groups) were scarified and stored frozen. Later, they were used in the removal of needed tissues. In total, 30 test fish individuals were investigated.

The following body tissues were selected for the determination of the amounts of HMs in fish: muscle without scales, gills (whole organ) and liver (whole organ).

After the morphometric analysis of fish has been performed, muscle, gills and liver were separated from bone tissue, and samples were taken (averagely $3-5 \mathrm{~g}$ of each for one fish).

The samples were dried in an oven and digested in aqua regia (concentrated $\mathrm{HNO}_{3}$ and $\mathrm{HCl}$ at a ratio of $1: 3 \mathrm{v} / \mathrm{v}$ ) for 50 minutes at a temperature $\sim 180{ }^{\circ} \mathrm{C}$ using microwave digestion system ETHOS (Milestone, USA). After cooling solutions were filtered through a $0.45 \mu \mathrm{m}$ glass filter and diluted with deionised water up to $50 \mathrm{ml}$. Metal concentrations were measured by atomic absorption spectrophotometry on AAS Buck Scientific 210VGP with flame or graphite furnace techniques in accordance with standardized procedures (LST ISO 11047:2004) final concentration being expressed as $\mathrm{mg} / \mathrm{kg}$ of wet weight.

The amount of oxygen in the tanks as well as temperature and $\mathrm{pH}$ was measured routinely with a hand-held multi-meter (WTW Multi 340i/SET, Germany). Nominal HM concentrations were checked during blank tests with an atomic absorption spectrophotometer (SHIMADZU AA-6800, Japan) by graphite furnace technique using proprietary software. Each sample was analysed three times. Mean measured concentrations were within $5-10 \%$ of the target.

It is well known that metal accumulation in fish is not static, but a dynamic process and bioconcentration is occurring when uptake from the water is greater than excretion. Bioconcentration factor (BCF) is used to quantify the bioconcentration potential in aquatic biota and is defined as the ratio of the concentration of the chemicals in the biota to that of water at equilibrium (Ivanciuc et al. 2006). Actually, the BCF is a measure of the extent of chemical partitioning between an organism and the surrounding environment. The values of BCF greater than 1,000 are considered high, less than 250 low, and those between are classified as moderate.

In our case BCF equals the milligrams of metal per kilogram fresh weight of the sample divided by the milligrams of the same metal per litre in the water.

The data were analysed statistically through STATISTICA 6.0 (StatSoft Inc., Tulsa, Oklahoma, USA) software. All the samples underwent distribution normality test. Then the significance of the differences between results was established using Student's $t$-test at $p \leq 0.05$.
Table 1. Heavy metal (HM) concentrations in a model mixture

\begin{tabular}{clc}
\hline $\begin{array}{r}\text { Heavy } \\
\text { metal } \\
(\mathrm{HM})\end{array}$ & \multicolumn{1}{c}{ Source } & $\begin{array}{c}\text { Maximum-Permissible- } \\
\text { Concentration (MPC) } \\
(\mathrm{mg} / \mathrm{l})\end{array}$ \\
\hline $\mathrm{Cu}$ & $\mathrm{CuSO}_{4} \cdot 5 \mathrm{H}_{2} \mathrm{O}$ & 0.01 \\
$\mathrm{Zn}$ & $\mathrm{ZnSO}_{4} \cdot 7 \mathrm{H}_{2} \mathrm{O}$ & 0.1 \\
$\mathrm{Ni}$ & $\mathrm{NiSO}_{4} \cdot 7 \mathrm{H}_{2} \mathrm{O}$ & 0.01 \\
$\mathrm{Cr}$ & $\mathrm{K}_{2} \mathrm{Cr}_{2} \mathrm{O}_{7}$ & 0.01 \\
$\mathrm{Cd}$ & $\mathrm{Cd}\left(\mathrm{CH}_{3} \mathrm{COO}\right)_{2} \cdot 2 \mathrm{H}_{2} \mathrm{O}$ & 0.005 \\
$\mathrm{~Pb}$ & $\mathrm{~Pb}\left(\mathrm{NO}_{3}\right)_{2}$ & 0.005 \\
\hline
\end{tabular}

\section{Results}

Obtained data showed (Figs 1-3) that in most cases, the amount of HMs in body tissues of HMMM-exposed fish was significantly higher as compared to control fish.

An exception was $\mathrm{Cu}$ in the muscle and liver, and $\mathrm{Cd}$ in the liver. The total amount of HMs in control fish liver was $0.51 \mathrm{mg} / \mathrm{kg}$, in gills $-2.20 \mathrm{mg} / \mathrm{kg}$ and in muscle $6.10 \mathrm{mg} / \mathrm{kg}$, while in HMMM-exposed fish, liver was 1.91, gills -3.0 and in muscle $-16.10 \mathrm{mg} / \mathrm{kg}$, respectively.

Heavy metal accumulation order in Gibel carp muscle and gills was as follows: $\mathrm{Zn}>\mathrm{Cu}>\mathrm{Ni}>\mathrm{Cr}>\mathrm{Pb}>\mathrm{Cd}$, while in liver $-\mathrm{Zn}>\mathrm{Cu}>\mathrm{Pb}>\mathrm{Ni}>\mathrm{Cr}>\mathrm{Cd}$.

The amount of Ni in HMMM-exposed fish gills increased by $118, \mathrm{Cd}-64, \mathrm{Zn}-37, \mathrm{Cu}-34, \mathrm{Cr}-22$ and $\mathrm{Pb}-18 \%$, respectively. The amount of $\mathrm{Zn}$ in HMMMexposed fish liver increased by $1,398, \mathrm{Cr}-63, \mathrm{Ni}-47$, $\mathrm{Pb}-21, \mathrm{Cu}-5.6$ and $\mathrm{Cd}-0.8 \%$, respectively.

Meanwhile, in muscle, the amounts of $\mathrm{Zn}$ increased by $183, \mathrm{~Pb}-178, \mathrm{Cr}-92, \mathrm{Cd}-79, \mathrm{Ni}-30$ and $\mathrm{Cu}-0.3 \%$, respectively, as compared with control fish.

The amount of $\mathrm{Ni}$ in test fish exposed to Ni separately increased in gills by 50 , in muscle -41 and in liver $31 \%$, respectively, as compared with control fish.

On the average, the total amount of HMs in HMMMexposed fish liver was by $224 \pm 196$, in muscle $-86 \pm 27$ and in gills $-49 \pm 13 \%$ higher as compared with control fish (mean \pm SEM, $n=6$, respectively).

Quantitatively maximum levels in the Gibel carp body tissues found were of $\mathrm{Zn}$ (Fig. 1), while the minimum of cadmium (Fig. 2). Copper was in the second place. Zinc was accumulated mostly in the muscle, at least in the liver.

Copper bioconcentration factor (BCF) in Gibel carp body tissues was as follows: in muscle -30 , gills -29 , and liver -22.

Zinc BCF in Gibel carp body tissues was as follows: in muscle -152 , gills -24 , and liver -14 .

Nickel BCF in Gibel carp body tissues were as follows: in muscle -28 , gills -14 , and liver -12 . 
Meanwhile, in the tests with Ni separately, its BCF in Gibel carp body tissues was as follows: in muscle - 30, gills - 10, and liver - 11 .

Chromium BCF in Gibel carp body tissues was as follows: in muscle -15 , gills -4 , and liver -10 .

Lead BCF in Gibel carp body tissues was as follows: in muscle - 32, gills - 31, and liver - 13 .

Cadmium BCF in Gibel carp body tissues was as follows: in muscle -7 , gills -4 , and liver -3 .

After the average values of factors $\left(\mathrm{BCF}_{\mathrm{av}}\right)$ were calculated, it has been established that the highest HM
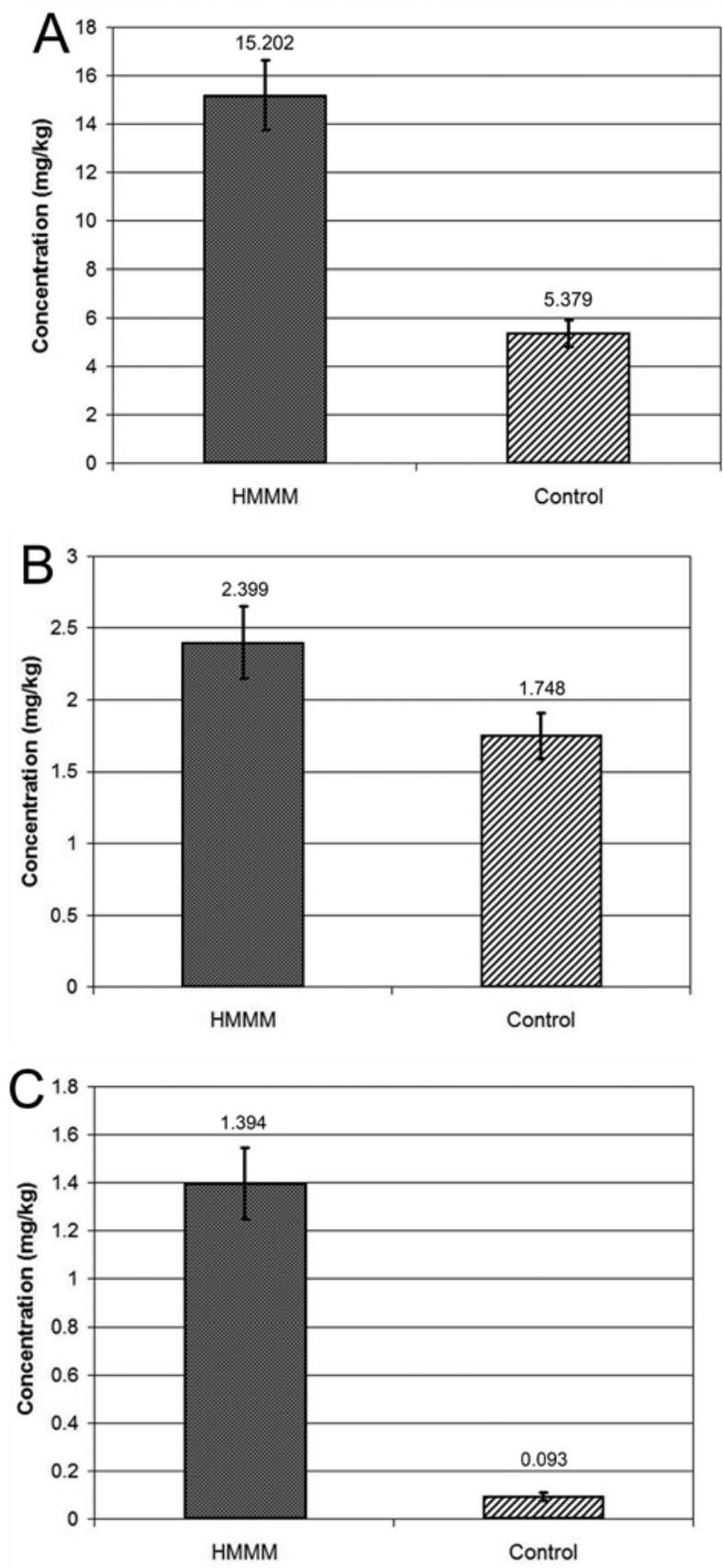

Fig. 1. Zinc concentration in body tissues of mixture-exposed Gibel carp (HMMM): muscle (A), gills (B) and liver (C) $($ Mean \pm SD). All test values are significantly different from control $(p<0.05)$ accumulation intensity was in Gibel carp muscle $\left(\mathrm{BCF}_{\mathrm{av} .}=\right.$ $42.0 \pm 18.7)$, then in gills $\left(\mathrm{BCF}_{\mathrm{av}}=16.6 \pm 4.3\right)$ and the lowest - in liver $\left(\mathrm{BCF}_{\mathrm{av}}=12.1 \pm 2.2\right)($ mean $\pm \mathrm{SEM}, n=7$, respectively).

However, no statistically significant differences between all these values were found ( $p>0.1$, one-way ANOVA). This indicates that HMs were accumulated in Gibel carp body tissues with averagely equal intensity. This means that the accumulation of HMs in a given tissue passed in a balanced countervailing way: an increase in one metal concentration was compensated by the
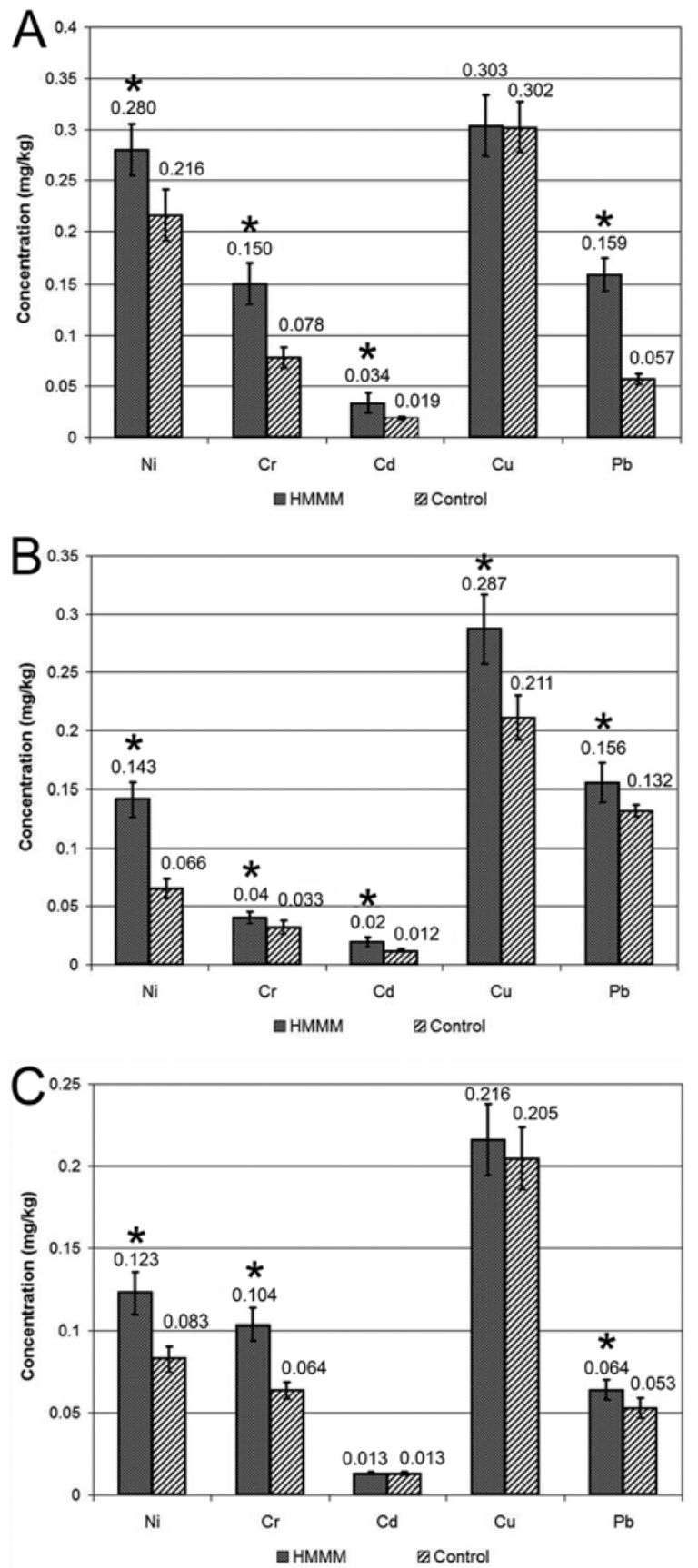

Fig. 2. Heavy metal concentration in body tissues of mixtureexposed Gibel carp (HMMM): muscle (A), gills (B) and liver (C) $\left(\right.$ Mean \pm SD). Asterisks $\left({ }^{*}\right)$ denote values significantly different from control $(p \leq 0.05)$ 

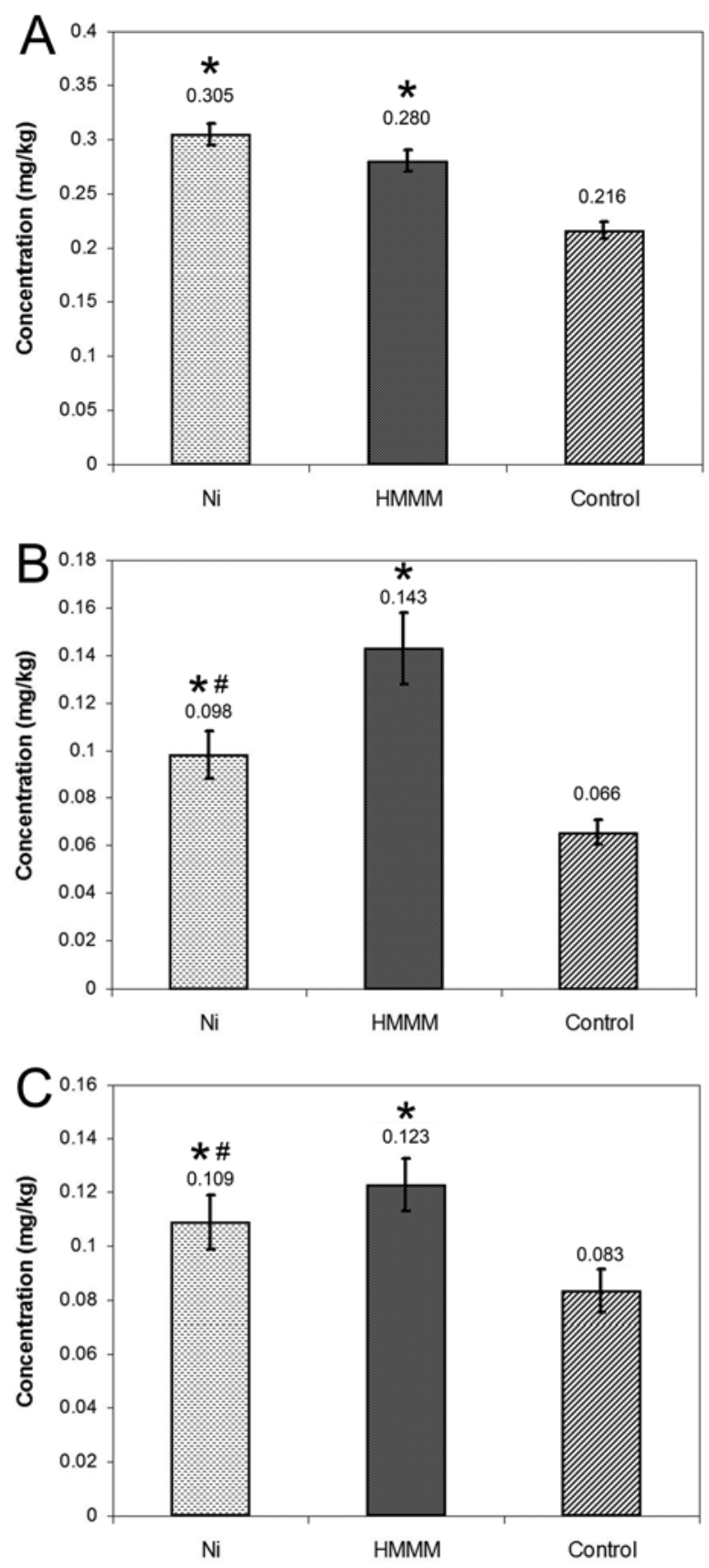

Fig. 3. Comparison of $\mathrm{Ni}$ concentration in $\mathrm{Ni}$-exposed $(\mathrm{Ni})$ and mixture-exposed (HMMM) Gibel carp body tissues: muscle (A), gills (B) and liver (C) $($ Mean $\pm \mathrm{SD})$. Asterisks $\left({ }^{*}\right)$ denote values significantly different from control, and grades (\#) denote significant differences between $\mathrm{Ni}$ and mixture-exposed fish at $p \leq 0.05$, respectively

less accumulation of the other and vice versa. This indicates an obvious interaction between metal accumulation relationships in tissues.

Similar results were obtained in a previous study (Idzelis et al. 2010) for rainbow trout and stone loach. Heavy metals were accumulated in different body tissues of both fish species with approximately the same total intensity.
Accumulation of $\mathrm{Ni}$ was significantly influenced by the presence of HMMM in the water. In the tests with $\mathrm{Ni}$, no significant difference between its contents in HMMMexposed and $\mathrm{Ni}$-exposed fish muscle was found (Fig. 3). Meanwhile, Ni concentrations in HMMM-exposed fish liver and gills were significantly higher than those in $\mathrm{Ni}$ exposed fish (by 11 and 31\%, respectively). This indicates that the presence of HM mixture in the water promotes $\mathrm{Ni}$ accumulation in test fish gills and liver under different experimental conditions. Presumably, this occurs due to the synergistic effects among the metals.

\section{Discussion}

Data obtained showed that HM accumulation in Gibel carp was metal and tissue specific, i.e. a different tissue showed different capacity for accumulating HMs. In general, all tissues contained high concentrations of $\mathrm{Zn}$ and $\mathrm{Cu}$, but a much lower concentrations of $\mathrm{Ni}, \mathrm{Cr}, \mathrm{Pb}$, and Cd. Such great differences in HM accumulation could be explained, apparently, by their reliance to different categories of HM as described by Roy (2010): essential metals, non-essential metals, etc.

The essential trace elements are those minerals which though needed in very low quantities are vital to the proper functioning of the various biological systems. A heavy metal is termed essential if its deficiency results in the impairment of a function. Nickel and $\mathrm{Cr}$ are non-essential HMs. These elements are harmless below their "threshold level" but when they exceed the threshold level, they become toxic and impair various vital functions (Roy 2010). Meanwhile, $\mathrm{Cd}$ and $\mathrm{Pb}$ are non-essential toxic heavy metals. These metals have no well known biological functions in the animal body and are toxic even in minimal quantities. Their toxicity is due in part to their competition with essential metals for binding sites and also their interference with sulfhydryl groups, which are essential for the normal functioning of enzymes and structural proteins (Da Silva et al. 2005).

Zinc and $\mathrm{Cu}$ are essential metals, their role in fish organism is important as they take part in metabolic activities, and their concentrations are under homeostatic control (Bury et al. 2003; Papagiannis et al. 2004). Many authors report that $\mathrm{Cu}$ accumulation in fish occurs only under exposure to elevated $\mathrm{Cu}$ concentrations (Grosell, Wood 2002). This conclusion could be successfully applied to our results because no differences in $\mathrm{Cu}$ content in the liver and muscle was found between the control and HMMM-exposed fish. The significant $\mathrm{Cu}$ increase was found in the gills which are the target organ of $\mathrm{Cu}$ toxicity and accumulation in fish (Kamunde et al. 2002a, b). The gills are obviously very susceptible to waterborne metals, and often show various metal induced lesions (Jezierska, Sarnowski 2002). The gills of teleost fish play an important 
role in ion regulation, gas exchange, acid-base balance, and nitrogenous waste excretion, thus playing a key role of the interface of the fish and their environment. The gills are assumed to be major sites of metal uptake due to the large surface area and direct contact with the aquatic environment (Grosell, Wood 2002). The total metal level in the gills depends upon the absorption of metals not only in the gill tissue but also due to their complexation with the increased amount of mucus onto the surface of the gills, and a number of recent studies confirm it (Oymak et al. 2009).

However, the above-mentioned statements could hardly be applied to $\mathrm{Zn}$ which content increased at the most of any in all Gibel carp tissues. Such intense increase in $\mathrm{Zn}$ concentration a bit surprises as many authors state that diet is normally the primary source of $\mathrm{Zn}$, and waterborne $\mathrm{Zn}$ can become significant only in the case when dietary supply is low (Bury et al. 2003). Furthermore, the highest content of $\mathrm{Zn}$ was found in muscle, the tissue which is generally recognized as the non-metal-accumulating site in freshwater fish (Has-Schön et al. 2006). The highest increase in $\mathrm{Zn}$ content was found in Gibel carp liver (15-fold). The liver has the ability to accumulate large amounts of HMs from the water and also plays an important role in their storage, redistribution, detoxification transformation and metabolisation, mainly through the induction of metal-binding proteins such as metallothioneins (Bury et al. 2003; Licata et al. 2005). Furthermore, $\mathrm{Zn}$ was fond to be a promoter of the synthesis of more metallothioneins (Sigel et al. 2009). The level of metallotioneins has been proposed to be an important biomarker of HM exposure in fish (Valavanidis et al. 2006; Schmitt et al. 2007; Roy et al. 2011).

Generally, liver accumulates high concentrations of metals, irrespectively of the uptake route. The liver is considered a good monitor of water pollution with metals since their concentrations accumulated in this organ are often proportional to those present in the environment. Metal levels in the liver rapidly increase during exposure, and remain high for a long time of depuration, when other organs are already cleared (Jezierska, Witeska 2006).

The data obtained in this study obviously contradict some findings by other authors. For example, Ribeyre et al. (1995) investigated the actions and interactions between five elements ( $\mathrm{Cu}, \mathrm{Ag}, \mathrm{Se}, \mathrm{Zn}$, and $\mathrm{Hg}$ ) toward their accumulation by zebrafish (Brachydanio rerio) from the direct route at the whole organism level at environmentally-relevant concentrations and found that the accumulation of $\mathrm{Zn}$ was not significantly affected by the concentrations of $\mathrm{Zn}$ in the water or by any of the other elements.

It is unlikely that $\mathrm{Zn}$ uptake was from the diet since both control and test fish were fed in the same manner with well-balanced proprietary fish feed. In any case, active uptake of $\mathrm{Zn}$ and other metals into fish tissues from the water is evident. It remains just to state that such remarkable increase in $\mathrm{Zn}$ concentration in all Gibel carp tissues could be explained at most of the high exposure concentration $(0.1 \mathrm{Zn} \mathrm{mg/l})$ among the metals and synergistic action between them. These differences in the results need further experimental revising.

Several studies have been devoted to the analysis of $\mathrm{Ni}$ accumulation in fish separately and at the presence of other metals in the water. Thus, Van Hoof and Nauwelaers (1984) exposed roach (Rutilus rutilus) for 24 hours to acutely lethal Ni concentrations of 50 and $100 \mathrm{mg} / \mathrm{l}$ separately and in binary mixtures with $\mathrm{Cr}$ and $\mathrm{Cu}$ at 80 and $1 \mathrm{mg} / \mathrm{l}$, respectively and found that in the separate exposures, the highest $\mathrm{Ni}$ concentration was found in the gills and the lowest in the muscle. While, simultaneous exposures to $\mathrm{Ni}+\mathrm{Cu}$ and $\mathrm{Ni}+\mathrm{Cr}$ resulted in a significant $\mathrm{Ni}$ levels increase in the gills and opercula. Sreedevi et al. (1992) exposed common carp (Cyprinus carpio) for 4-12 days to sublethal and lethal $\mathrm{Ni}$ concentrations ( 8 and $40 \mathrm{mg} / \mathrm{l}$, respectively) and found that the accumulation intensity was time and concentration-depended. The accumulation of $\mathrm{Ni}$ was in the order: gill $>$ kidney $>$ liver $>$ brain $>$ muscle. Palaniappan and Karthikeyan (2009) studied the accumulation and elimination of $\mathrm{Cr}$ separately and in the binary mixture with $\mathrm{Ni}$ in Cirrhinus mrigala at sublethal concentrations of $2.9 \mathrm{mg} / \mathrm{l}$ for seven days and found that the combined exposure induced higher nickel accumulation in fish by $10-28 \%$. This, in turn, determined an increase of $7-12 \% \mathrm{Cr}$ in the presence of Ni. The accumulation of both nickel and chromium was in the order: kidney $>$ liver $>$ gill $>$ muscle. Similarly, Vinodhini and Narayanan (2008) exposed common carp (Cyprinus carpio) for 1-62 days to a mixture of metals $(\mathrm{Cr}, \mathrm{Ni}, \mathrm{Cd}$ and $\mathrm{Pb}$ ) at sublethal concentrations corresponding to their 0.01 of 48 -hour LC50 and found that the accumulation order varied greatly depending on the fish organ, the proportion of $\mathrm{Cd}$ and $\mathrm{Pb}$ being the highest in the tissues. Karthikeyan et al. (2009) reported that the accumulation of $\mathrm{Ni}$ in Cirrhinus mrigala exposed to sublethal concentrations ranging from 1.05 to $4.6 \mathrm{mg} \mathrm{Ni} / \mathrm{l}$ was significantly influenced by water $\mathrm{pH}$ and hardness. It increased when $\mathrm{pH}$ increased and decreased when hardness increased. However, the accumulation order remained unaffected: kidney $>$ liver $>$ gills $>$ muscle.

Summarizing all these results it should be concluded that our data confirm these findings only partly. It is evident that the presence of the metal mixture in the water stimulated $\mathrm{Ni}$ accumulation in the gills and liver of Gibel carp, but not in the muscle. However, the accumulation orders in HMMM-exposed and Ni-exposed Gibel carp were quite different as compared with those above-mentioned: muscle $>$ gills $>$ liver and muscle $>$ gills $=$ liver, respectively. Therefore, muscle is the primary tissue of $\mathrm{Ni}$ accumulation as in the case with $\mathrm{Zn}$. So far, this phenomenon is difficult to explain. Perhaps, it depends not only on Gibel carp species-specific accumulative-metabolic 
activity properties but also on the exposure concentration. The reason for this as well could be low concentrations of exposure, which were several orders of magnitude lower than those in above-mentioned experiments. Perhaps, HM accumulation from the direct route at low concentrations follows quite different patterns as compared to those nearly-lethal of even lethal ambient concentrations, and this pattern becomes evident only at low concentrations. All of these queries still need to have the answers.

It is remarkable that here the muscle was found to be a target organ for HM accumulation in Gibel carp. Overall, this study has raised a number of questions, the answers to which must be obtained from further, more exhaustive experimental investigations.

In this study, Maximum-Permissible-Amounts (MPA) in fish indicated in the Lithuanian hygiene standard HN 54:2001: Zn-40, Cu-10, Ni-0.5, Cr-0.3, Pb-0.2 and Cd- $0.05 \mathrm{mg} / \mathrm{kg}$ of raw mass, respectively (Projekto... 2004) in all cases were not exceeded, i.e. they were below the recommended levels for human consumption. However, in previous studies under the same experimental conditions, it has been established that $\mathrm{Ni}, \mathrm{Pb}$ and $\mathrm{Cd}$ concentrations exceeded above-mentioned limits in the body tissues of roach, perch, stone loach and rainbow trout (Idzelis et al. 2008, 2010). In natural environments, HMs can migrate into fish organism not only from surrounding medium but also through food-objects (trophic chain) thus, further increasing their amount in the tissues. Furthermore, HMs even at low concentrations can increase their accumulation in fish due to the actions and interactions between the metals. Therefore, the obtained results require continuous control of HMs in fish, although their concentrations in ambient water do not exceed MPC.

These experimental results coincide with data of environmental monitoring where it has been established that HM concentrations in fishes from natural water bodies rarely exceed MPA (Projekto... 2004). An exception was determined for $\mathrm{Ni}$ and $\mathrm{Pb}$, which often exceed these limits.

Heavy metal accumulation order in Gibel carp organ tissues was following: muscle > gills > liver. Meanwhile, under the same experimental conditions in the tissues of roach and perch, they were accumulated as follows: liver $>$ muscle $>$ gills, in stone loach: gills $>$ liver $>$ muscle, and quite contrary in rainbow trout: muscle $>$ liver $>$ gills (Idzelis et al. 2008, 2010). Without discussing possible mechanisms it is evident that HM accumulates from the water into the tissues of ecologically different fish species (roach and Gibel carp refer to freshwater limnophilous benthophagous species, stone loach - freshwater rheophylous benthophagous, perch - freshwater limnophilous euryphagous and rainbow trout - anadromous rheophylous-limnophilous euryphagous) quantitatively diversely and specifically.
Although, at present, a lot of data on HM accumulation in fish from natural water-bodies and experimentally are compiled the interspecific differences of this process still remains investigated insufficiently. Evidently, that this depends on the HM chemical origin, the presence of other HMs in the water, fish species-specific ecological, behavioural and their organism biochemical-physiological properties. Further, more exhaustive experimental investigation into HM accumulation patterns in various fish species is evident.

\section{Conclusions}

1. Heavy metal (HM) concentration increased significantly in most cases in body tissues of Gibel carp (muscle, gills and liver) after 14-day exposure to HM model mixture (HMMM) and to Ni separately, at concentrations corresponding to Maximum-Permissible-Concentrations (MPC) accepted for the inland waters of Lithuania: Cu-0.01, Zn-0.1, Ni-0.01, Cr-0.01, Pb-0.005 and Cd-0.005 mg/l, respectively.

2. Heavy metal accumulation order in body tissues of Gibel carp was following: muscle $>$ gills $>$ liver. The highest amounts found were of zinc $(15.2 \mathrm{mg} / \mathrm{kg})$, while the lowest of cadmium $(0.012 \mathrm{mg} / \mathrm{kg})$.

3. In the muscle and gills, HMs were accumulated in such decreasing order: $\mathrm{Zn}>\mathrm{Cu}>\mathrm{Ni}>\mathrm{Cr}>\mathrm{Pb}>\mathrm{Cd}$, while in the liver: $\mathrm{Zn}>\mathrm{Cu}>\mathrm{Pb}>\mathrm{Ni}>\mathrm{Cr}>\mathrm{Cd}$. Heavy metals were accumulated in Gibel carp body tissues with approximately the same total intensity: no significant differences between average values of bioconcentration factors $\left(\mathrm{BCF}_{\mathrm{av}}\right)$ were found $(p>0.1)$.

4. Accumulation of $\mathrm{Ni}$ was significantly influenced by the presence of HMMM in the water. It promoted $\mathrm{Ni}$ accumulation in test fish gills and liver under different experimental conditions (by 11 and $31 \%$, respectively). Presumably, this occurs due to the synergistic effects among the metals.

5. Although the concentrations of HMs in Gibel carp body tissues increased, they were below the recommended levels (Maximum-Permissible-Amounts) (MPA) for human consumption.

6. Data obtained here, and in previous studies under the same experimental conditions confirmed that HMs accumulation in different fish species is highly specific and their amounts sometimes exceed MPA (especially $\mathrm{Ni}, \mathrm{Pb}$ and $\mathrm{Cd}$ ). These results coincide with the data of environmental monitoring of HMs in fishes from natural water bodies and, apparently, depend on the HM chemical origin, fish ecological, behavioural and their organism biochemical-physiological process properties.

7. The obtained results require continuous control of HMs in fish although their concentrations in ambient water do not exceed MPC. 


\section{References}

Bury, N. R.; Walker, P. A.; Glover, C. N. 2003. Nutritive metal uptake in teleost fish, The Journal of Experimental Biology 206(Pt 1): 11-23. http://dx.doi.org/10.1242/jeb.00068

Canli, M.; Atli, G. 2003. The relationships between heavy metal $(\mathrm{Cd}, \mathrm{Cr}, \mathrm{Cu}, \mathrm{Fe}, \mathrm{Pb}, \mathrm{Zn})$ levels and the size of six Mediterranean fish species, Environmental Pollution 121(1): 129-136. http://dx.doi.org/10.1016/S0269-7491(02)00194-X

Chovanec, A.; Hofer, R.; Schiemer, F. 2003. Fishes as bioindicators, in B. A. Markert; A. M. Breure; H. G. Zechmeister (Eds.). Bioindicators and biomonitors, principles, concepts and applications. Amsterdam: Elsevier, 639-676. http://dx.doi.org/10.1016/S0927-5215(03)80148-0

Clearwater, S. J.; Farag, A. M.; Meyer, J. S. 2002. Bioavailability and toxicity of dietborne copper and zinc to fish, Comparative Biochemistry and Physiology. Part C: Toxicological Pharmacology 132(3): 269-313.

Da Silva, A. L. O.; Barrocas, P. R. G.; Jacob, S. C.; Mreira, J. C. 2005. Dietary intake and health effects of selected toxic elements, Brazilian Journal of Plants Physiology 17(1): 79-93. http://dx.doi.org/10.1590/S1677-04202005000100007

Directive 2000/60/EC of the European Parliament and of the Council establishing a framework for Community action in the field of water policy. 2000, CELEX-EUR Official Journal of the European Communities L 327: 1-72.

Ghosh, L.; Adhikari, S. 2006. Accumulation of heavy metals in freshwater fish - an assessment of toxic interactions with calcium, American Journal of Food Technology 1(2): 139-148. http://dx.doi.org/10.3923/ajft.2006.139.148

Ghosh, L.; Adhikari, S.; Ayyappan, S. 2007. Assessment of toxic interactions of heavy metals and their effects on accumulation in tissues of freshwater fish, Research Journal of Environmental Toxicology 1(1): 37-44.

http://dx.doi.org/10.3923/rjet.2007.37.44

Green, N. W.; Knutzen J. 2003. Organohalogens and metals in marine fish and mussels and some relationships to biological variables at reference localities in Norway, Marine Pollution Bulletin 46(3): 362-377.

http://dx.doi.org/10.1016/S0025-326X(02)00515-5

Grosell, M.; Wood, C. M. 2002. Copper uptake across rainbow trout gills: mechanisms of apical entry, The Journal of Experimental Biology 205(8): 1179-1188.

Has-Schön, E.; Bogut, I.; Strelec, I. 2006. Heavy metal profile in five fish species included in human diet, domiciled in the end flow of river Neretva (Croatia), Archives of Environmental Contamination and Toxicology 50(4): 545-551. http://dx.doi.org/10.1007/s00244-005-0047-2

Idzelis, R. L.; Kesminas, V.; Svecevičius, G.; Misius, V. 2008. Accumulation of heavy metals $(\mathrm{Cu}, \mathrm{Zn}, \mathrm{Ni}, \mathrm{Cr}, \mathrm{Pb}, \mathrm{Cd})$ in tissues of perch (Perca fluviatilis L.) and roach Rutilus rutilus (L.) under experimental conditions, Journal of Environmental Enginnering and Landscape Management 16(4): 205-212. http://dx.doi.org/10.3846/1648-6897.2008.16.205-212

Idzelis, R. L.; Kesminas, V.; Svecevičius, G.; Venclovas, A. 2010. Experimental investigation of heavy metal accumulation in tissues of stone loach Noemacheilus barbatulus (L.) and rainbow trout Oncorhynchus mykiss (Walbaum) exposed to a model mixture $(\mathrm{Cu}, \mathrm{Zn}, \mathrm{Ni}, \mathrm{Cr}, \mathrm{Pb}, \mathrm{Cd})$, Journal of Environmental Engineering and Landscape Management 18(2): 111-117. http://dx.doi.org/10.3846/1648-6897.2010.13
Ivanciuc, T.; Ivanciuc, O.; Klein, D. J. 2006. Modeling the bioconcentration factors and bioaccumulation factors of polychlorinated biphenyls with posetic quantitative super-structure/ activity relationships (QSSAR), Molecular Diversity 10(2): 133-145. http://dx.doi.org/10.1007/s11030-005-9003-3

Jezierska, B.; Sarnowski, P. 2002. The effect of mercury, copper and cadmium during single and combined exposure on oxygen consumption of Oncorhynchus mykiss (WAL.) and $\mathrm{Cu}$ prinus carpio (L.) larvae, Archives of Polish Fisheries 10(1): $15-22$.

Jezierska, B.; Witeska, M. 2006. The metal uptake and accumulation in fish living in polluted waters, in I. Twardowska et al. (Eds.). Soil and water pollution monitoring, protection and remediation. Springer, 3-23.

Kamunde, C.; Grosell, M.; Higgs, D.; Wood, C. M. 2002a. Copper metabolism in actively growing rainbow trout (Oncorhynchus mykiss): interactions between dietary and waterborne copper uptake, The Journal of Experimental Biology 205: 279-290.

Kamunde, C.; Clayton, C.; Wood, C. W. 2002b. Waterborne vs. dietary copper uptake in rainbow trout and the effects of previous waterborne copper exposure, The American Journal of Physiology-Regulatory, Integrative and Comparative Physiology 283(1): 69-78.

Karthikeyan, S.; Palaniappan, P. L. R. M.; Sabhanayakam, S. 2007. Influence of $\mathrm{pH}$ and water hardness upon nickel accumulation in edible fish Cirrhinus mrigala, Journal of Environmental Biology 28(2): 489-492.

Klavins, M.; Potapovics, O.; Rodinov, V. 2009. Heavy metals in fish from lakes in Latvia: concentrations and trends of changes, Bulletin of Environmental Contamination and Toxicology 82(1): 96-100. http://dx.doi.org/10.1007/s00128-008-9510-x

Licata, P.; Trombetta, D.; Cristani, M.; Naccari, C.; Martino, D.; Calo, M.; Naccari, F. 2005. Heavy metals in liver and muscle of bluefin tuna (Thunnus thynnus) caght in the straits of Messina (Sicily, Italy), Environmental Monitoring and Assessment 107(1-3): 239-248.

http://dx.doi.org/10.1007/s10661-005-2382-1

LST ISO 11047:2004. Dirvožemio kokybe. Kadmio, chromo, kobalto, vario, švino, mangano, nikelio ir cinko nustatymas ekstrahuojant dirvožemi karališkuoju vandeniu. Liepsnos ir elektroterminès atomines absorbcijos spektrometriniai metodai (tapatus ISO 11047:1998) [Soil quality. Determination of cadmium, chromium, cobalt, copper, lead, manganese, nickel and zinc in aqua regia extracts of soil. Flame and electrothermal atomic absorption spectrometric methods (idt ISO 11047:1998)]. Lietuvos standartizacijos departamentas. 18 p.

Luczynska, J.; Tonska, E. 2006. The effect of fish size on the content of zinc, iron, copper, and manganese in the muscles of perch (Perca fluviatilis L.) and pike (Esox lucius L.), Archives of Polish Fisheries 14(1): 5-13.

Nemova, N. N. 2005. Biochemical effects of accumulation of mercury in fish. Moscow: Nauka. 164 p. (in Russian).

Oymak, S. A.; Karadede-Akin, H.; Dogan, N. 2009. Heavy metal in tissues of Tor grypus from Atatürk Dam Lake, Euphrates River-Turkey, Journal of Biologia 64(1): 151-155.

Palaniappan, P. L. R. M.; Karthikeyan, S. 2009. Bioaccumulation and depuration of chromium in the selected organs and whole body tissues of freshwater fish Cirrhinus mrigala individually and in binary solutions with nickel, Journal of Environmental Sciences 21(2): 229-236. http://dx.doi.org/10.1016/S1001-0742(08)62256-1 
Papagiannis, I.; Kagalou, I.; Petridis, D.; Kalfakaou, V. 2004. Copper and zinc in four freshwater fish species from Lake Pamvotis (Greece), Environmental International 30(3): 357-362. http://dx.doi.org/10.1016/j.envint.2003.08.002

Polak-Juszczak, L. 2009. Temporal trends in the bioaccumulation of trace metals in herring, sprat, and cod from the southern Baltic Sea in the 1994-2003 period, Chemosphere 76(10): 1334-1339. http://dx.doi.org/10.1016/j.chemosphere.2009.06.030

Projekto „Sunkiuju metalų kaupimasis žuvyse ir dugno nuosedose“ rezultaty apžvalga [online], [cited 20 May 2011]. 2004. Available from Internet: http://oldaaa.gamta.lt/VI/article. php3?article_id=1203 (in Lithuanian).

Ribeyre, F.; Amiard-Triquet, C.; Boudou, A.; Amiard, J. C. 1995. Experimental study of interactions between five trace elements - $\mathrm{Cu}, \mathrm{Ag}, \mathrm{Se}, \mathrm{Zn}$, and $\mathrm{Hg}$ - toward their bioaccumulation by fish (Brachydanio rerio) from the direct route, Ecotoxicology and Environmental Safety 32(1): 1-11. http://dx.doi.org/10.1006/eesa.1995.1078

Roy, S. P. 2010. Overview of heavy metals and aquatic environment with notes on their recovery, Ecoscan: An International Quarterly Journal of Environmental Sciences 4(2-3): 235-240.

Roy, S. U.; Chattopadhyay, B.; Datta, S.; Kumar, S. 2011. Metallothionein as a biomarker to assess the effects of pollution on Indian major carp species from wastewater-fed fishponds of East Calcutta wetlands (a Ramsar Site) Mukhopadhyay, Environmental Research, Engineering and Management 4(58): 10-17.

Schmitt, C. J.; Whyte, J. J.; Roberts, A. P.; Annis, M. L.; May, T. W.; Tillitt, D. E. 2007. Biomarkers of metal exposure in fish from lead-zinc mining areas of Southeastern Missouri, USA, Ecotoxicology and Environmental Safety 67(1): 31-47. http://dx.doi.org/10.1016/j.ecoenv.2006.12.011
Sigel, A.; Sigel, H.; Sigel, R. K. O. (Eds.). 2009. Metallothioneins and related chelators. Metal ions in life sciences, vol. 5. Cambridge: RSC Publishing. $514 \mathrm{p}$. http://dx.doi.org/10.1039/9781847559531

Sreedevi, P.; Suresh, A.; Sivaramakrishnan, B.; Prabhavathi, B. 1992. Bioaccumulation of nickel in the organs of the freshwater fish, Cyprinus carpio, and the freshwater mussel, Lamellidens marginalis, under lethal and sublethal nickel, Chemosphere 24(1): 29-36. http://dx.doi.org/10.1016/0045-6535(92)90564-8

US EPA. 2009. National recommended water quality criteria [online], [cited 24 August 2013]. Office of Water, Office of Science and Technology (4304T), Washington, DC. 25. Available from Internet: http://www.rsc.org/dose/

Valavanidis, A.; Vlahogianni, T.; Dassenakis, M.; Scoullos, M. 2006. Molecular biomarkers of oxidative stress in aquatic organisms in relation to toxic environmental pollutants, Ecotoxicology and Environmental Safety 64(2): 178-189. http://dx.doi.org/10.1016/j.ecoenv.2005.03.013

Van Briesen, J. M.; Small, M. J.; Weber, C.; Wilson, J. 2010. Modeling chemical speciation: thermodynamics, kinetics, and uncertainty, in G. Hanrahan (Ed.). Modeling of pollutants in complex environmental systems, vol. 2, 133-149.

Van Hoof, F.; Nauwelaers, J. P. 1984. Distribution of nickel in the roach Rutilus rutilus L. after exposure to lethal and sublethal concentrations, Chemosphere 13(9): 1053-1058. http://dx.doi.org/10.1016/0045-6535(84)90064-X

Vinodhini, R.; Narayanan, M. 2008. Bioaccumulation of heavy metals in organ of freshwater fish Cyprinus carpio (Common carp), International Journal of Environmental Science and Technology 5(2): 179-182. http://dx.doi.org/10.1007/BF03326011

Gintaras SVECEVIČIUS. Dr, Senior Research Worker, Division of Ecological Physiology and Toxicology, Laboratory of Ecology and Physiology of Hydrobionts, Institute of Ecology of the Nature Research Centre. Doctor of Natural Sciences, 1993; Laureate of Lithuanian Science Award, 2007. Publications: author/co-author of $\sim 150$ scientific papers. Research interests: ecotoxicology, ichthyotoxicology, fish behavioural toxicology.

Raimondas Leopoldas IDZELIS. Dr, Assoc. Prof., Department of Environmental Protection, Vilnius Gediminas Technical University (VGTU). Doctor of Natural Sciences, 1993. Publications: author/co-author of $\sim 70$ scientific papers, 2 study guides, co-author of 3 monographs. Research interests: landscape management, ecology, environmental protection, animal guide urbanization.

Eglè MOCKUTE். Master of Science, Vilnius Gediminas Technical University (VGTU), 2011. Publications: co-author of 1 research paper. Research interests: environmental protection, accumulation of heavy metals, pollution prevention. 